\title{
The Role of Government Initiated Urban Planning Experiments in Transition Processes and Their Contribution to Change at the Regime Level
}

\author{
Caroline Newton (ID
}

Citation: Newton, C. The Role of Government Initiated Urban

Planning Experiments in Transition Processes and Their Contribution to Change at the Regime Level. Sustainability 2021, 13, 2419. https://doi.org/10.3390/su13052419

Academic Editor: Manuel

Duarte Pinheiro

Received: 19 January 2021

Accepted: 18 February 2021

Published: 24 February 2021

Publisher's Note: MDPI stays neutral with regard to jurisdictional claims in published maps and institutional affiliations.

Copyright: (c) 2021 by the author Licensee MDPI, Basel, Switzerland This article is an open access article distributed under the terms and conditions of the Creative Commons Attribution (CC BY) license (https:// creativecommons.org/licenses/by/ $4.0 /)$.
Department of Urbanism, Faculty of Architecture and the Built Environment, Delft University of Technology (TU Delft), Julianalaan 134, 2628 BL Delft, The Netherlands; c.e.l.newton-1@tudelft.nl

\begin{abstract}
Sustainable urban (planning) experiments play a crucial role in transitions and are tangible ways to contribute to innovation and change in the long run. This paper discusses how urban experiments contribute to sustainability transitions by explicitly looking at an urban experiment's capability to influence the regime level. The consequences of spatial inertia and political actors' involvement are two understudied aspects concerning urban experiments. The paper aims to introduce these two understudied aspects and suggests further research on both in current urban experimentation practices. First, the paper suggests spatial embeddedness as a relevant explanatory factor. Experiments that alter spatial structures or realize physical interventions on a neighborhood scale can anchor innovations in space. In doing so, they increase their sustainability in the long run. Secondly, the article contributes to the literature on institutions and politics in urban experiments. The article uses a literature study and a case to illustrate both points.
\end{abstract}

Keywords: sustainability transitions; urban planning; urban experiments

\section{Introduction}

The acceleration in land-use changes, turning untouched natural areas into urban built-up spaces impacts the urban vulnerability to zoonotic diseases [1]. Transformations of the living environment, triggered by climate change, affect people's mobility in the short and long term, whereby people are forced or choose to migrate in search of better living conditions [2]. These are just two examples that illustrate the increase of global challenges. Whereas during the 1980s climate change was troubling first activists and concerned citizens, and later politicians and policymakers, the gradual addition of more crises (from the financial crisis to migration and refugee crises and most recently a global health crisis) challenge our present model of society.

To deal with these challenges, changes in the current way of doing things become unavoidable. The broader acknowledgement of climate change's effects gave rise to local actions since the end of the 1980s [3]. The variety of these actions, from demonstration projects to specific urban interventions, illustrate the ad-hoc approach typical of that time. Challenges were addressed when they occurred, or when funding or interest in the issue was available $[3,4]$. The rapid increase of these exploratory actions and governance experiments triggered academic curiosity and led to a growing number of publications on transition experiments. Some publications describe particular experiments [5,6], other focus on one specific aspect, such as co-creation [7], while still others try to categorize experiments [4] or develop frameworks that support learning from the different cases [8]. The proliferation of literature has not necessarily led to an understanding of how these experiments in transition "support individual and organizational learning promoting ongoing change and up-scaling impact" [8]. Evans et al. [9] pose the critical question of whether urban experiments are just an extension of the business as usual or if they can actually "generate real alternatives and stimulate profound transformation?" This longing 
for profound transformation is one of the most fundamental arguments for experimentation. The challenge of generating (ongoing) change through urban planning experiments is at the heart of this contribution. Luederitz [8] reiterates: "Importantly, the sustainability practices experimented on do not concern mere modification or "tinkering" of elements already present. Instead, they are radically different from the status quo, in both process and outcomes [10-12]". This statement is entirely different from settling for 'urban improvement' [4]. Bulkeley et al. [4] argue that underlying political dynamics limit the scope and possible impact of urban experiments. However, political interference should not be a reason to settle for less than a radical reshaping of the traditional ways of doing when engaging in an urban experiment or urban living lab. On the contrary, urban experiments can facilitate novel governance arrangements to overcome political interference in transformative experiments and projects. Until now, more profound research on the role of governments in enabling change through urban experiments is somewhat limited. Mukhtar-Landgren et al. [13] have looked into the role of municipalities and local government. This article unpacks the role of institutions at the national and regional level and the impact of political involvement in urban experimentation.

The second understudied aspect concerning urban experiments that this article sheds light on is the importance of spatially anchoring innovation. Four aspects impact urban planning experiments' ability to influence the regime level. Three of these aspects (networks, mutual learning and co-design, strong vision) have been extensively discussed in the transition literature $[5,7,14-17]$. This article suggests that in urban planning experiments, spatial embeddedness is a criterion that adds to the understanding of the experiments impact on the regime level.

The consequences of spatial inertia and political actors' involvement are two understudied aspects concerning urban experiments. The paper aims to introduce these two understudied aspects and suggest further exploration of both in current urban experimentation practices.

To achieve this aim, the article uses a literature study and a case to illustrate both points. Part three contains the literature review, the case of the Pilot Project BiC (Back into Circulation) is elaborated in part four. Part two discusses the method used to collect data on BiC, an urban experiment developed by the team of Flanders' State Architect, that addresses urgent societal questions through spatial planning and design experiments.

The relevance of including spatial embeddedness as an explanatory factor is elaborated in section four, where the case is used as an illustration. Through this case, lessons learned also contribute to the discussion in part five on the role and involvement of political actors.

The conclusion then stresses that when political actors are involved in urban planning experiments, the need for transcendence of party politics is imperative to an ensuring state that stimulates innovation and innovative practices and delivers on their outcomes.

\section{Method: Immersive Research}

Between 2014 and 2017, the author was the coordinator of an urban planning experiment, initiated by regional administrations. This first-hand experience has the benefit of unlimited access to data and information, but also comes with numerous challenges, similar to those of an immersive research approach. Immersive research is a method where the researcher is absorbed within the setting (s)he is researching [18-20]. Because of the specific role as coordinator, there was full access to all the information about the project and experiential learning about procedures, processes and power structures within governmental settings.

Several benefits raised by Abraham et al. [18] had a significant impact on the knowledge and information acquired.

First, the direct observation of the stakeholders' power dynamics was further scrutinized through personal discussions with their representatives on several occasions and in different settings. This high level of accessibility is only possible because of this immersive setting. It was also possible to understand the evolution of the project 'from within'. 
Identifying sensitive information and dynamics that often stay hidden to the outsiders is probably the most valuable aspect of this immersive approach in this context. Often in research on urban experiments, the researcher comes in at a certain point and observes the experiment with outsiders' eyes, often unaware of hidden issues, especially those from before the time of engagement. In this specific situation, it was possible to uncover the political dimension. The prominent presence of political actors had first strongly influenced the project's framing and secondly ensured that sensitive issues (such as the shortcomings of existing policies, e.g., the brownfield policy) were left as untouched as possible.

This immersive approach also has its shortcomings. One of the partners financed the project coordinator, other partners could be afraid of a possible bias, despite all attempts to frame the coordinator function as an objective one. A more significant shortcoming is probably the ethical consideration of writing contributions using insider information to deconstruct the practice under discussion [21]. More specifically, there is a worry about trust relations with direct colleagues or those who represent the different stakeholders. Previous articles or presentations (when the author was still coordinating the project) stated that the presented opinions did not necessarily reflect the author's employer's official opinion at that time. Table 1 summarizes the relevant benefits and challenges of the immersive approach concerning the case of the Pilot Project BiC.

Table 1. Benefits and challenges of an immersive approach concerning the case of the Pilot Project BiC.

\begin{tabular}{|c|c|}
\hline \multicolumn{2}{|l|}{ Benefits } \\
\hline Immersive learning & $\begin{array}{l}\text { The long involvement ( } 3 \text { years) allowed for a more nuanced and layered understanding of } \\
\text { people's and institutions' actions and decisions compared to conventional research whereby } \\
\text { the researcher gathers knowledge only during a limited amount of time and often through } \\
\text { actors' recollection of past events. }\end{array}$ \\
\hline Experimental learning & $\begin{array}{l}\text { By being part of a government institution, the author experienced the direct impact of } \\
\text { governance systems, internal hierarchies, power struggles between institutions and the } \\
\text { political interferences. These led to extended conversations with administrators on their } \\
\text { previous experiences and led to valuable insights about the political frontstage and its impact } \\
\text { on the administration's backstage. }\end{array}$ \\
\hline Accessibility & $\begin{array}{l}\text { High-level administrators and cabinet members were easily approached. Colleagues at } \\
\text { different departments were comfortable sharing information, experiences and concerns. The } \\
\text { multiple meetings and workshops provided ample opportunities to talk to many people that } \\
\text { would otherwise not be interviewed. }\end{array}$ \\
\hline Hidden and sensitive information & $\begin{array}{l}\text { Because of the author's specific role (coordinator) and the long engagement and } \\
\text { consequential rapport building, access to information that would often stay out of sight in } \\
\text { conventional research was easily accessed. }\end{array}$ \\
\hline Direct observation & $\begin{array}{l}\text { Thanks to being directly involved, the author observed that certain practices and processes } \\
\text { help explain outsiders' misinterpretation of certain events. }\end{array}$ \\
\hline Action-oriented & $\begin{array}{c}\text { Throughout the process, the author experienced firsthand which practices and actions impact } \\
\text { the urban experiment's possibilities to impact the regime level. }\end{array}$ \\
\hline \multicolumn{2}{|l|}{ Challenges } \\
\hline Biased information & $\begin{array}{l}\text { More than with conventional research, the researchers' findings risk becoming influenced due } \\
\text { to the engagement and rapport with certain people. }\end{array}$ \\
\hline Ethics & $\begin{array}{l}\text { A significant challenge is using insider information to deconstruct the practice under } \\
\text { discussion. More specifically, this can impact trust relations with direct colleagues or those } \\
\text { who represent the different stakeholders. }\end{array}$ \\
\hline
\end{tabular}

\section{Sustainable Transitions and the Role of Urban Planning Experiments \\ 3.1. Profound Processes of Change}

Being at a crucial moment in time, global crises such as climate change or migration and the increasing inequality and the realization that our earth is a finite resource are all triggers that could abruptly alter the status quo. Unfortunately, as Giddens [22] argued, 
most of these challenges "aren't tangible, immediate or visible in the course of day-to-day life" that is why for most people actions to address these challenges are not high on the agenda. However, not addressing them today ultimately leads to their unsolvability in the long run. Already today, rising levels of uncertainty give way to increased turmoil, protest and fear. Crises offer a chance for change, existing institutions and ways of doing can and should be, questioned. The search for new value systems becomes increasingly apparent [23].

Current challenges and problems are so deeply rooted in our society's structure and consequently in our day to day practices so that any change towards new systems will require both new (daily) practices and profound structural change [23]. Grin et al. [23] define transitions as "profound processes of change", as "shifts from one socio-technical system to another". Transitions are long term processes, whereby multiple actors are working through different levels to achieve "the reconfiguration of the institutional and organizational structures and systems of society" $[23,24]$.

Today the focus of envisaged transitions is mostly on sustainability, whereby climate change and related ecological process are the centers of attention. Technical innovations are often considered as possible solutions. However, despite acknowledging that technological innovation is crucial, a successful transition can only happen when there is sufficient attention for the social, economic, and cultural contexts and changes. More importantly, and reinforcing Swilling and Annecke's [24] argument, the imagined transition does not only result in "a mode of production and consumption that is not dependent on resource depletion and environmental degradation", but is also a just transition, thus one that addresses the socio-economical inequalities and global poverty. Thus, transitions are co-evolution processes, addressing multiple issues in multiple domains. Interaction between different domains can shape and reinforce each other, without determining them completely [23,25]. Consequently, multiple stakeholders will be involved. The way these stakeholders are involved, and the co-design and co-learning process they go through together are essential for forming a joint (new) approach and future direction. Using a case, part four discusses these stakeholders' role and the institutional setting's challenges. First, the role of urban experiments in transition processes is discussed.

\subsection{Urban Planning Experiments as Stepping Stones in Processes of Profound Change}

Transition is a multi-level process, and change is needed on all the three levels: the (innovative) practices, the regime level and the long-term (40-50 years) trends (mostly referred to as the landscape) [16,25-28]. These levels discuss degrees of structuration and not spatial scales [23]. The regime level holds the rules and frameworks that govern the actors' action and possibilities. The landscape is the exogenous structure in which these actions can occur (see Figure 1). The transition from a linear economic model to a circular one is exemplary. After years of experimentation on a small scale (both within grassroots organizations and within a governmental setting, e.g., Plan-C in Flanders), the publication of a groundbreaking report by Ellen MacArthur Foundation [29] managed to put 'circular economy' on the international agenda. Within a decade a fully circular economy will likely be the new landscape against which production logics and rules and regulations will be framed in the future. 


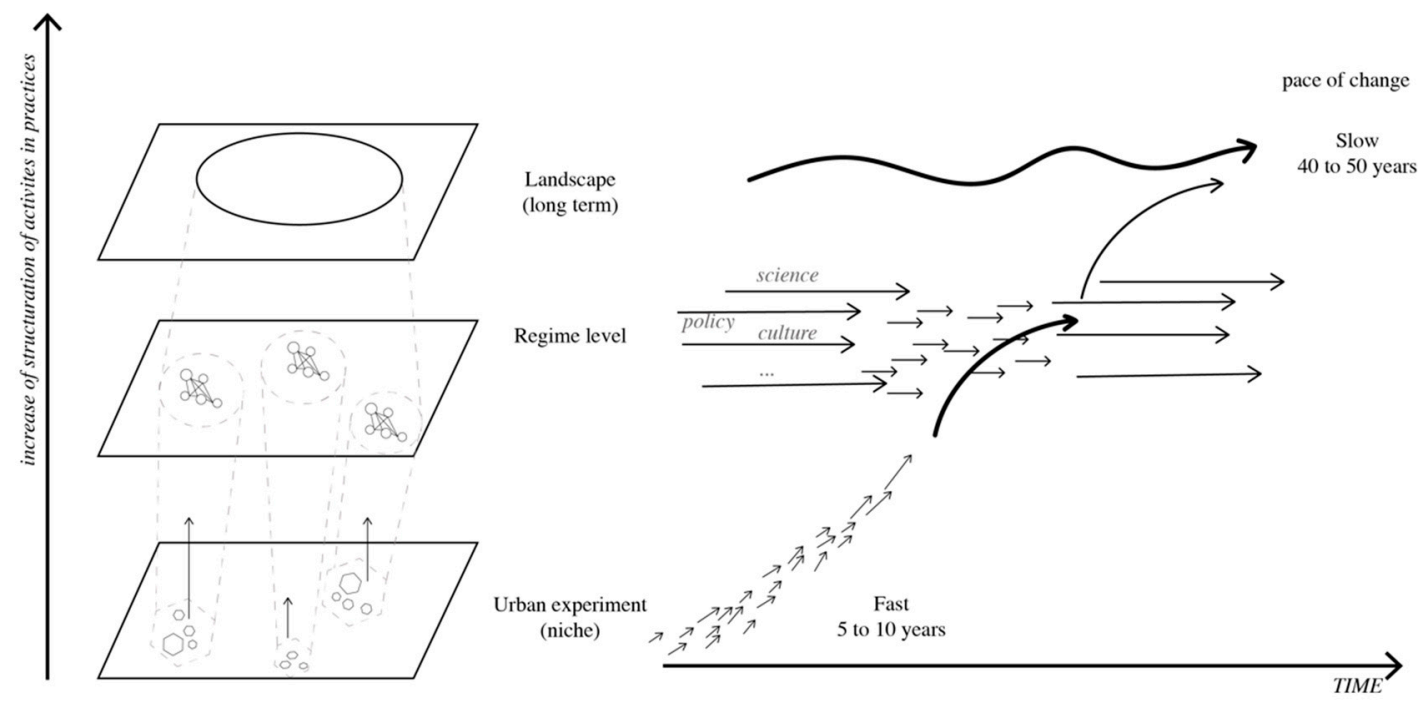

Figure 1. The multi-level perspective on transitions, also showing the increase of structuration of activities and the increase of components aggregated in the structure $[16,27,28]$.

This multi-level perspective (MLP) on transitions offers a solid framework to understand urban experiments' role in reaching profound and ongoing change. However, because this framework is rooted in technological innovation studies, additional reflections on the specifics of innovations and experiments in a spatial and urban setting are required.

Figure 1 shows the multiple levels in which a close relation between actors, structures and practices emerge, the higher the level, the slower the dynamics and higher the complexity because of the increased number of components (and relations between them). Urban experiments play an essential role in this level of innovative practice. They are the potential triggers for novelties and generating new ways of doing. However, their potential to catalyze ongoing change and eventually influence transitions depends heavily on how they align or penetrate existing regimes (see Figure 1). When experiments can ensure that ideas and practices translate into rules, policy agendas and legislation, a significant step towards ongoing change is taken $[23,27,28,30]$. At least three aspects impact the possible success of this integration: (1) A strong vision and the clear articulation of this vision and expectations that come with it, (2) a resilient and robust network and (3) a mutual learning process. A fourth element, namely the spatial embeddedness, needs to be added to this framework. These four aspects are discussed in section four and in relation to the Pilot Projects BiC.

Urban experiments have taken on many forms, but in essence, they are about learning how change is created in a controlled environment [31], the controlled environment can provide the needed safe space for experimentation. Urban experiments are thus understood as a niche, a safe setting that nurtures radical innovation [32], and one that is embedded in the local city scale and leads to real outcomes on the local level $[5,9,13]$. Searching for ways to share the knowledge and the learning experience beyond the experiments' immediate boundaries is challenging, creating an impact at the regime level even more. Hoogma et al. [33] introduce two measures to evaluate early niche development's success: the quality of learning and the quality of institutional embeddedness. Especially for innovations that serve a broad societal goal and for which the sense of urgency is high, such as the Pilot Project $\mathrm{BiC}$, institutional embedding and linkage with a vast network of relevant actors and stakeholders are crucial $[16,26]$. The link between the experiment and the institutional level can be arranged by establishing transition arenas. Loorbach [17] defines a transition arena as "a small network of frontrunners with different backgrounds, within which various perceptions of a specific persistent problem and possible directions for solutions can be deliberately confronted with each other and subsequently integrated". It is essential to create a setting where these frontrunners can work autonomously and that the knowledge 
and approaches can move to an institutional level. The importance of these arenas is unpacked later in this paper.

\section{Pilot Projects BiC as Urban Planning Experiment}

The "pilootprojecten" is a specific planning and design instrument developed by Flanders' State Architect's team in 2011. The name given to this instrument is confusing because it is often assumed that they are just 'a' pilot project, an initial small-scale implementation of an idea that serves to test its viability. Although this is also the case for the "pilootprojecten", in addition, strict protocols and rules are in place. The instrument uses experiments to address urgent societal questions through design. Since 2011 a series of Pilot Projects were launched: Invisible Care (2012), Collective Housing (2013), Productive Landscape (2013), Commissioned Art (2014), Back In Circulation (BiC) (2014), Students Make City (2016), Climate Areas (2018). The Pilot Project Commissioned Art explored traditional art commission practices' boundaries to reflect the diversity of contemporary artistic production. The Pilot Projects Student Make City demonstrate that future student housing can be a motor for neighborhood development.

The illustrative case of the Pilot Projects used in this paper emerged out of a concern about the substantial number of unused and abandoned industrial sites in Flanders. A recent calculation done by VLAIO (Flanders department of innovation and entrepreneurship) estimates that 1724 hectares of business parks are currently abandoned, 179 hectares is being redeveloped. Besides, almost 4000 business spaces are abandoned, and over 1500 are in a severe state of neglect [34]. These underused sites have the potential to be redeveloped. The consortium that came together to address this question stated that the redevelopment should not merely be about the site's reactivation, but through its reactivation, other societal challenges should be addressed. Finally, it was decided that the rejuvenation and redevelopment of underused and abandoned former industrial sites (a), characterized by soil pollution (b); should uphold the principles of the circular economy (c) while attracting local manufacturing (d).

For each theme, a Pilot Projects program usually consists of five exemplary projects. To ensure realization in the short term, the number of selected projects is purposefully kept to a limit. A Pilot Projects program consists of essential components and phases, as illustrated in Figure 2.

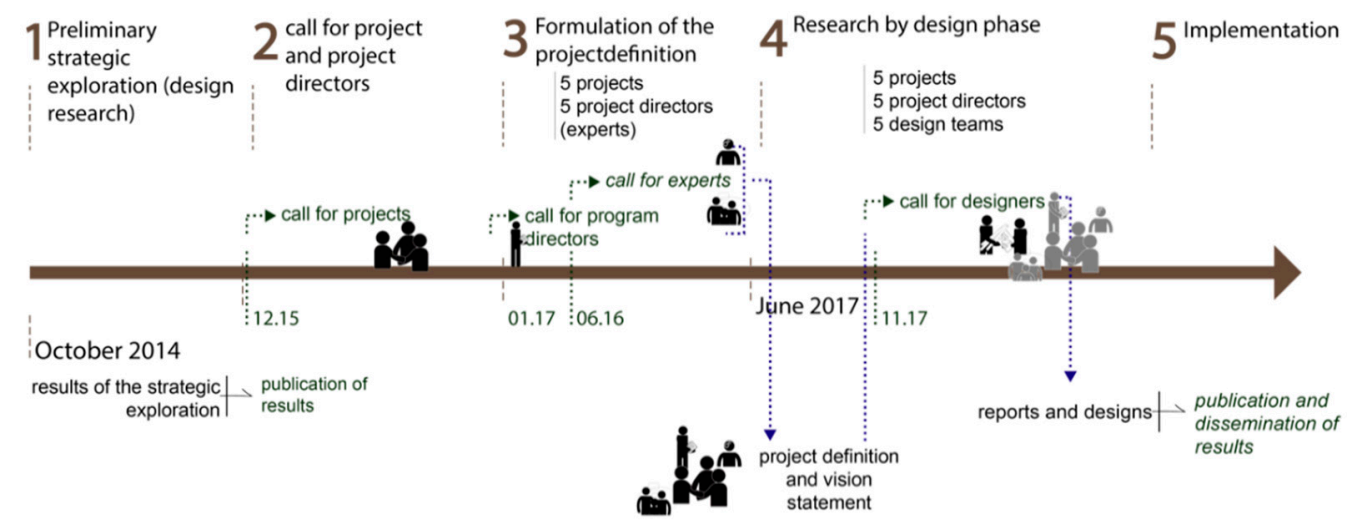

Figure 2. Timeline Pilot Project BiC.

The steering committee oversees the five pilot projects and has the decision power. They select the projects, and in the second and third phase, they select the project manager and the design team for each of the projects (see Figure 2). The steering committee comprises representatives of the minister's cabinets and departments of relevant policy domains. In most of the Pilot Projects, one minister is involved, but given the complexity of the Pilot Project BiC, four ministers and five agencies are involved. In addition to 
the representatives, two independent experts and the project coordinator are part of the committee (see Figure 3).

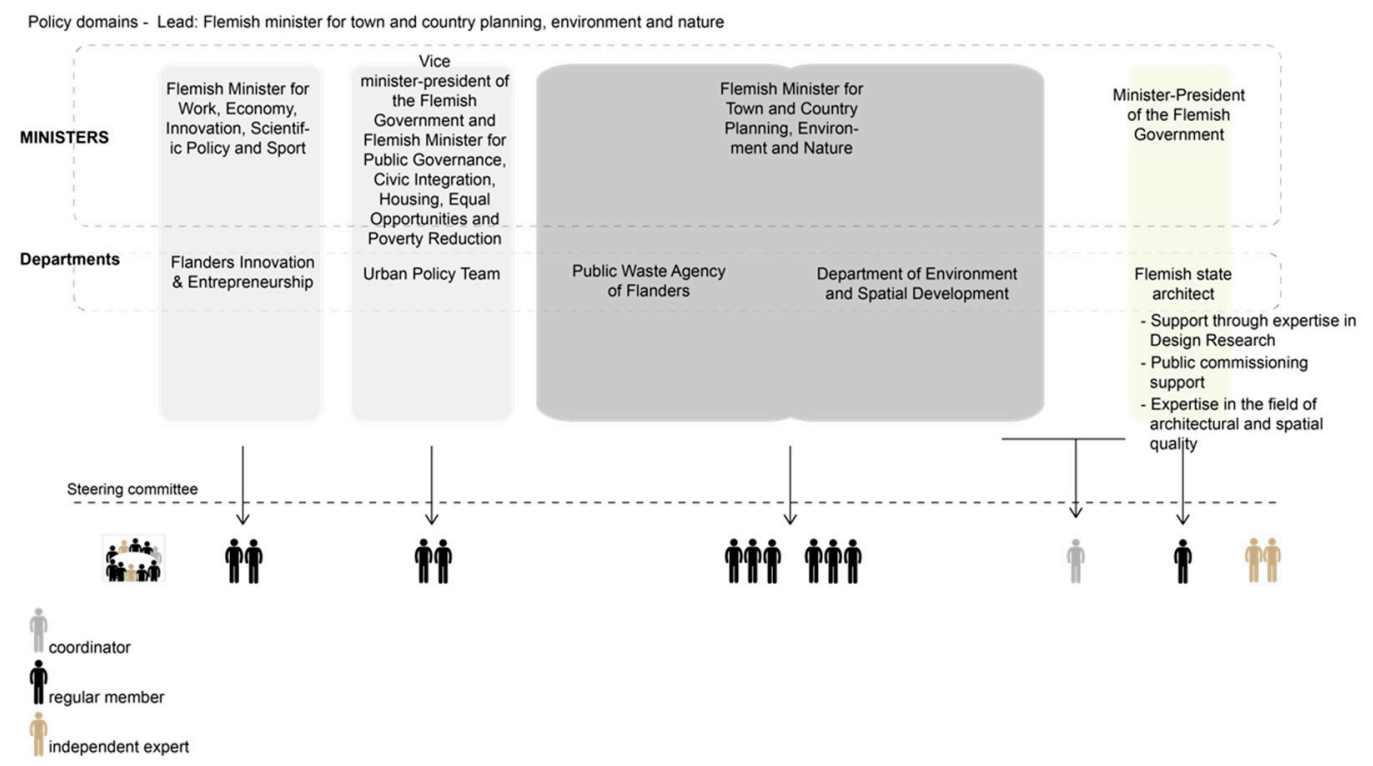

Figure 3. Project structure Pilot Project BiC.

After the projects were selected, a call was launched to find project directors for each of these projects. They are the communicative pivot and responsible for the process that leads to a realizable project. (s)He ensures that all aspects of the project are always taken into account, organizes the cooperation between all parties involved and the consultation with licensing authorities. The project director is committed to realizing the client's ambitions and expectations without losing sight of the ambitions of the overarching project objectives of the Pilot Projects BiC. The five project directors meet regularly to clarify the project definitions and design assignments and enable knowledge exchange. Although the aim is to have the five projects progress simultaneously, this was impossible with the BiC project because of the projects' diversity. Consequently, not all projects are yet in a phase of completion, the scale and the number of actors involved have a significant impact on the pace of the different projects.

The Pilot Project BiC are a typical niche. Rip [32] initially used the niche concept to refer to a safe setting that provides the needed protection and nurturing of new ideas and radical technology innovation. Without such a safe space, these ideas and novelties, often lacking sufficient legitimacy at their inception, are easily eliminated [16]. To assess whether the Pilot Project BiC has penetrated the regime level, the following sections will address the three relevant criteria (networks, mutual learning and co-design, strong vision) $[16,26,33]$ and introduce spatial embeddedness as an additional explanatory factor. Although discussed separately, their mutual influence is vital in understanding how the regime level was successfully influenced.

\subsection{Networks}

Led by the Flemish State architect, the strategic partners guaranteed an environment (see Figure 3) in which out of the box ideas and approaches to answer the questions can be nurtured. This safe space was created through different kinds of support and a platform for deliberation and learning. The strategic partners guarantee an adequate budget for design research, master planning (or architectural design) and supervision. Besides, they try to loosen the regulatory frameworks to support innovation and experimentation. A flexible licensing policy is being pursued. Facilitating this 'minimal regulatory context' ensures that projects can represent a new benchmark. Figure 3 shows the involvement of five Flemish departments and four ministers. The steering committee aimed to have 
a horizontal platform for deliberation and learning, where all participants were on an equal foot. In theory, it looks as if a broad (different views, from different fields) and deep (representatives of the organizations have sufficient authority to mobilize capacity and funds) network is available. However, in reality, political actors' proximity proved very challenging.

In contrast to a science lab, where all the conditions are being controlled meticulously, urban labs, in which the experiments occur, are more difficult to control. On the other hand, they offer a great opportunity of learning to deal with uncertainty and local contingencies [31]. Thus, experiments need to embrace the risk of failure, which is not necessarily a problem but rather a different learning experience. This risk has materialized itself in several of the Pilot Projects, and although these failures have provided interesting learning points, they were considered problematic by the political partners. This is mostly because of the instrument's specific organizational design. Because the projects are supported directly by a specific minister, the projects risk to become politically sensitive and could potentially be used by the opposition to question the minister and his or her actions and choices. When the instrument was designed, the collaboration with a minister was intended to facilitate a setting that allows a free interpretation of existing legal frameworks. However, especially for the more complex projects, this close link between politics and experiments proved detrimental for innovation and potentially limits urban experiments' success, discussed in more detail in part five.

\subsection{Learning and Co-Design}

McFarlane [35] argues that learning "is more than just a set of mundane practical questions, but is central to political strategies that seek to consolidate, challenge, alter and name new urban worlds". Thus, learning is essential in seeking alternatives and assessing better practices and approaches. By engaging in a debate with others, who have different practices, knowledge is shared. McFarlane [35] places learning at the heart of the urban agenda. A critical evaluation of existing urban practices and the exploration of possible alternatives are the first steps towards change. In urban experiments, this evaluation of the existing and the exploration of alternative options is indeed a central concern. In the Pilot Project instrument, learning is an explicit aim: the results of the projects, the process and the evaluation of the experience is extensively communicated, to stakeholders, experts, but also the larger society.

Pilot Projects are perfect loci for learning through doing and through experiencing, as such they provide a chance to expand the learning beyond first order (merely accumulating facts, numbers and figures) to include collective value learning [23,33]. Gaining insights into other positions and ideas allows these new ideas to gradually spread more widely, penetrate institutions [30] and become anchored at the regime level. In the $\mathrm{BiC}$ project, the learning has led to directly questioning the existing policies for the regeneration of brownfields. In 2017 criteria for sustainable development and circular economy were included in the brownfield covenant selection criteria, which illustrates how lessons that come from first-order learning lead to quick-fix remediation of existing shortcomings [25]. This is only a first tiny step. More challenging is to align values and positions during negotiations, affecting the possible mobilization of the needed resources and political engagements, especially in the long-term [15]. Even more importantly, the Pilot Project BiC has also questioned existing decision and organization structures, but real innovation in governance was never achieved. The Pilot Project $\mathrm{BiC}$ attempted to work in a horizontal structure, whereby the project itself would always be the central concern of the actors involved. It is the task of the project coordinator to safeguard this. The complexity of the project, its relevance for a broad number of sectors and governmental agencies triggered this need for a horizontal structure in which all partners are equal and whereby the aims of the project were put before the internal politics of the different agencies involved. A different way of working, from a classical hierarchical approach to an open and flat structure was needed to achieve this. The project coordinator is supposed to be in a 
neutral position, almost working as a liaisons officer, linking and bridging the different departments. However, sustaining this rhizomatic decision-making over a more extended period proved to be challenging, and the structure eroded to become the classical project committee in which the different partners try to ensure the priorities of their departments are covered.

Fortunately, two other factors impact the possible successful influence of urban planning experiments at the regime level. A clear and robust vision and spatial embeddedness are two aspects that push urban experiments further.

\subsection{Strong Vision and Management of Expectations}

In the first stage of the project, the vision and the focus of the BiC-project were developed in more detail [36]. The Pilot Projects BiC acknowledges the potential of neglected and polluted urban terrains as motors for an integrated redevelopment in which the circular economy's principles are at the core of the development. The potential of an integrated and participatory redevelopment is tested in five real projects. It was expected that using real projects, the innovation and the potentials for transition could be proved and broadly communicated, engaging potential investors, developers, and ordinary citizens to take similar initiatives.

Effective and robust communication about the image of an alternative urban future, anchored in core values, seeks to engage the broader public. Pieterse refers to Malik's [37] description of a city that is "democratic, productive, innovative and sustainable as well as cultural, creative and tolerant". There are parallels between the urban future envisaged in the Pilot Projects BiC and the Vision 2050 [38] of the Flemish government. The Flemish government engages itself to "create prosperity and well-being in a smart, innovative and sustainable way, in a social, open, resilient and internationally-connected Flanders, in which every individual counts". The underlying principles in both are normative (a future sustainable and resilient city based on the principles of an inclusive circular economy of making). Communicating these in such a way that they can be adopted by a broader audience and more specifically by private actors, who often still operate within classical neoliberal market thinking, is part of the mission of the Pilot Project BiC. "Iconic communication" (pp. 64-65, [39]) strategies are needed. Within a short moment in time, the projects need to communicate their impact and significance. However, because of the close collaboration with four ministers and five different governmental agencies, rapid official communication was almost impossible. Proposals needed to be agreed upon by all the parties, the official visual language needed to be agreed on and all partners needed to decide who would launch certain communications.

Nevertheless, thanks to the close collaboration with grassroots, creative entrepreneurs and local makers, the initiatives developed their proper communication strategies. The initiatives, facilitated through the Pilot Project BiC start to live a life of their own, allowing them to reach a broad audience and inspire with glimpses of the possible future (see as an example https:/ / blikfabriek.be/ (accessed on 18 February 2021) or https: / / timelab.org (accessed on 18 February 2021)). The negotiated official communication, using the official platforms and official visual language, is hardly inspiring. Although one could argue that this is but a minor issue, it is symptomatic of the strenuous co-existence exercise that numerous innovative actions and programs, initiated through governmental agencies face. The strong vision is partly lost in the dry official communications.

\subsection{Spatial Embeddedness}

Urban experiments come in different shapes and forms; their categorization has been the topic of many publications e.g., [4]. Successful experiments ultimately create new or different socio-material conditions [4]. The process governs human conduct and even establishes new forms of conduct, often improving the old ways of doing.

When the urban experiment is predominantly about altered or new physical or spatial organizations, the possible impact is extended. Grin et al. [23] remind us that the phase 
of innovative practices (see also Figure 1) often takes a longer time than expected. The timeframe of innovative practices and experimental initiatives can take up to a decade before they become integrated at the regime level. These long timeframes are a challenge for urban experiments because they are led, coordinated and run by people, actors and institutions with particular reasons for engagements and their specific motivations. Keeping all of these actors on board for the time needed is a huge challenge that impacts urban experiments' possible success.

The Pilot Projects BiC uses five real projects; the potential of an integrated and participatory redevelopment is tested on the ground. After an initial phase of selection, the five projects embark on their particular trajectory towards realization. Trajectories often run in parallel; however, because of the complexity of the $\mathrm{BiC}$ project, the five projects are all in different stages. Most of the Pilot Projects deliver a masterplan within three to four years; this will not be the case for the $\mathrm{BiC}$ projects, because of their scale and complexity. There is a substantial potential risk that comes with this long timeframe of realization. Fatigue or loss of interest can occur along the way. However, the projects have one enforcing advantage, their spatial embeddedness. Not one single project stays at the level of master planning. Implementation of the project is underway: buildings are refurbished, and the government makes land acquisitions. On several sites, temporary use is established.

Urban experiments that have an important spatial component, such as planning and design experiments, anchor the vision, ideas and principles of the experiment for the longer run. Although this spatial anchoring is a strength, it also has possible side-effects. Once an idea is anchored in space, it is difficult to correct it if the effects become unfavorable. The inertia of space seriously impacts future possibilities, both in the positive and the negative sense. More in-depth research on this aspect can provide additional insights on triggers for transition.

\section{Discussion: Broadening the Transition Arena?}

Dealing with crises can be done in two ways. One way is to worry about the present and the fear of losing out. The other way is to look hopeful towards the future. In this latter approach, a crisis is embraced as "a leap of hope" [40]. Pieterse [41] argues that an ethics of transgression is needed, whereby the existing limits, the existing boundaries are considered as 'conditions of possibility'. Pushing existing boundaries and crossing over the existing limitations is imperative for creating a possible new (urban) future. These visions of new urban futures are to be grounded in the values of sustainable development and social-spatial justice. The current political and institutional setting in Flanders cannot implement these kinds of visions, and the current political and administrative structures are unable to foster the realization of the ambitions formulated in the Vision 2050. The experiences of the Pilot Projects (experiments that foster the transgression and look for alternative future models) are not entirely positive. Creating change on an even higher level is far more challenging. In order to come to "vibrant politics" and "politics of transgression, pleasure, joy and social justice" [39,42] a different framework is needed.

Pieterse brings forward the idea of 'epistemic communities' who can come up with new ideas, possess creativity and design and develop ways forward. These epistemic communities comprise of "organic intellectuals, who are actively involved in society, striving to change it rather than maintain tradition" [39] (p. 135). These engaged citizens can take action in complicated settings based on intellectual work and practical judgement. They can develop alternatives to dominant and hegemonic ideas and practices and find ways to embed these ideas within the mainstream gradually. For Pieterse, such an epistemic community cannot emerge or stay within the state or civil society organizations, but it must find its place in the holes and gaps between state, civil society, grassroots, academia, and the private sector. This notion of the epistemic community finds a connection to Loorbach's [17] frontrunners of the transition arena. However, while Pieterse stresses distance from institutions, the MLP framework discussed throughout this paper has made it clear that experiments that successfully impact the regime level and thus influence policy 
and legislation will need to connect to institutional actors at a certain point. Whereas epistemic communities are crucial and indispensable in the formulation and exploration of innovative ideas and progressive practices, a wider transition arena, where regime-actors are partners, is imperative to change institutions and the regime level [23]. In such a broader transition arena, niche thinkers and actors' ideas and experiences can influence institutions' frames at the regime level $[23,30]$.

An essential role of the epistemic communities is to influence existing institutions, government structures and associations. Consequently, it is crucial to be at a respectful distance to allow critical reflection on these structures and institutions.

Institutions have a fundamental role in facilitating transition. Institutionalization occurs when practices become sufficiently regular and continuous [30]. Institutionalization is thus about the incorporation of change. Change is sustained over time when institutions absorb alternative practices and ideas and optimize their organization to operationalize these alternatives optimally [30]. Levy's "web of institutionalization" [30] provides a framework for understanding the process's complexity. The framework highlights thirteen aspects that influence the possibilities of a full institutionalization of alternative practices (in our case, urban experiments). At least two aspects are crucial for the absorption of niches or urban experiments into the regime level. Firstly, the policy sphere needs to acknowledge the relevance of the issue and be willing to address it. In the Pilot Projects this is clear, as the government, through its different departments and institutions, are the initiators.

Additionally, this willingness needs to translate into policies and, notably, budget allocation. In the next step, the institutions themselves need to be (re-)structured, allowing innovation realized to the fullest. Thus, the organization's hardware is redesigned, the necessary procedures are put in place, and the required human capital attracted [30]. The alternative urban future will not be built using existing models. New governance models are required to build our urban futures to come.

In the case of the Pilot Projects, the impact of the political is a source of concern. The co-existence between a political "frontstage" where politicians and high government officials are confronted with public media and opposition parties (thus always careful about how to communicate) and a 'backstage' of administrators and innovative thinkers who are trying to push the boundaries and who work towards an envisaged urban future, needs to be rethought if governments are serious (and honest) about the visions they project. According to Mouffe [43], "agonistic confrontation, far from representing a danger to democracy, is, in reality, the very condition of its existence. (...) democracy (...) must also enable the agonistic expression of conflict, which requires that citizens genuinely have the possibility of choosing between real alternatives". These alternatives exist and are continuously developed further, different visions and ideas (presented by the grassroots) are being explored. Engaged administrators are looking for ways to transgress, to move into a different future. Unfortunately, the political frontstage is often too preoccupied with staying in power, curtailing administrators' ambition and investment in progressive ideas. With the Pilot Project BiC, it became clear that efforts to go beyond the limits (in any form and in this case, existing policies, practices and convictions), paradoxically can reinforce them $[4,44,45]$.

However, it is imperative to stay "at the frontiers" and transform them into "a practical critique that takes the form of a possible transgression" [46].

It remains crucial that regime level actors such as governments and their institutions stay involved in niches, especially in those experiments that explore alternative approaches in the socio-spatial field. These niches can provide a safe environment in which innovation and change are nurtured. Governmental support can also subsidize projects and initiatives that are not yet considered profitable (in the broadest sense, not merely in monetary terms), but that can help realize future societal goals, such as a more just and sustainable city [16]. Giddens [22] stresses that an "ensuring state" is needed to develop an approach to climate change. Thus, a state that enables, facilitates and supports grassroots initiatives. However, facilitating is not enough for Giddens; the state also needs to "deliver outcomes"; thus 
"the state is responsible for monitoring public goals and for trying to make sure they are realized in a visible and acceptable fashion" [22]. The biggest challenge can be found at the political level. Giddens argues that in this current time, and in dealing with climate change issues, one should transcend party politics.

\section{Conclusions: Beyond Party Politics}

In this paper, the contribution of urban experiments to sustainability transitions was addressed by explicitly looking at how an urban experiment, as a niche, is (un)able to penetrate the regime level. More specifically, the paper aimed to highlight two understudied aspects concerning urban experiments.

First, spatial embeddedness is suggested as a fourth explanatory factor (in addition to having a strong vision, a robust network and a process of mutual learning). Secondly, the role of government institutions and political actors has been addressed.

In the discussion, the fragile balance between systemic communities (or frontrunners) and a process of institutionalization, happening at an administrative backstage that is (sometimes firmly) influenced by a political frontstage, has been unpacked. Based on these reflections and the $\mathrm{BiC}$ project experiences, attention is drawn to the need for further research on this fragile balance and the possible impact of the political frontstage on the success of urban experiments. So, although Gidden's idea of the ensuring state could be an excellent opportunity to improve the absorption of urban experiments into the regime level, the experiences gathered as being part of the transition arena of the BiC project, suggests that this will mostly ask changes on the political level and less so on the level of the institutions. Urban planning experiments such as the Pilot Projects are transition arenas, bringing together both niche actors and regime actors, facilitating mutual learning, knowledge production and understanding. Nevertheless, political actors that dare to transcend party politics are needed within this arena. Only when party divisions are transcended, innovations with a high sense of urgency and significant social relevance can be legitimized to both the constituents and the population at large.

Funding: This research received no external funding.

Institutional Review Board Statement: Not applicable.

Informed Consent Statement: Not applicable.

Data Availability Statement: Not applicable.

Conflicts of Interest: The author declares no conflict of interest.

\section{References}

1. Keil, R.; Ali, H. Governing the Sick City: Urban Governance in the Age of Emerging Infectious Disease. Antipode 2007, 39 , 846-873. [CrossRef] [PubMed]

2. Ionesco, D.; Mokhnacheva, D.; Gemenne, F. Atlas of Environmental Migration; Routledge: London, UK, 2017; ISBN 978-1-138-02206-5.

3. Bulkeley, H.; Castán Broto, V. Government by Experiment? Global Cities and the Governing of Climate Change. Trans. Inst. Br. Geogr. 2013, 38, 361-375. [CrossRef]

4. Bulkeley, H.; Marvin, S.; Palgan, Y.V.; McCormick, K.; Breitfuss-Loidl, M.; Mai, L.; von Wirth, T.; Frantzeskaki, N. Urban Living Laboratories: Conducting the Experimental City? Eur. Urban Reg. Stud. 2019, 26, 317-335. [CrossRef]

5. Wendler, J. Grassroots experimentation Alternative learning and innovation in the Prinzessinnengarten, Berlin. In The Experimental City; Evans, J., Karvonen, A., Raven, R., Eds.; Routledge: London, UK, 2016; pp. 150-162.

6. Bos, J.J.; Brown, R.R. Governance Experimentation and Factors of Success in Socio-Technical Transitions in the Urban Water Sector. Technol. Forecast. Soc. Chang. 2012, 79, 1340-1353. [CrossRef]

7. Puerari, E.; de Koning, J.I.J.C.; von Wirth, T.; Karré, P.M.; Mulder, I.J.; Loorbach, D. Co-Creation Dynamics in Urban Living Labs. Sustain. Switz. 2018, 10, 1893. [CrossRef]

8. Luederitz, C.; Schäpke, N.; Wiek, A.; Lang, D.J.; Bergmann, M.; Bos, J.J.; Burch, S.; Davies, A.; Evans, J.; König, A.; et al. Learning through Evaluation-A Tentative Evaluative Scheme for Sustainability Transition Experiments. J. Clean. Prod. 2017, 169, 61-76. [CrossRef]

9. Evans, J.; Karvonen, A.; Raven, R. The Experimental City; Routledge: London, UK, 2016; ISBN 9781138856202. 
10. Evans, J.; Karvonen, A. “Give Me a Laboratory and I Will Lower Your Carbon Footprint!"-Urban Laboratories and the Governance of Low-Carbon Futures. Int. J. Urban Reg. Res. 2014, 38, 413-430. [CrossRef]

11. Bernstein, M.J.; Wiek, A.; Brundiers, K.; Pearson, K.; Minowitz, A.; Kay, B.; Golub, A. Mitigating Urban Sprawl Effects: A Collaborative Tree and Shade Intervention in Phoenix, Arizona, USA. Local Environ. 2016, 21, 414-431. [CrossRef]

12. Davies, A.R.; Doyle, R. Transforming Household Consumption: From Backcasting to HomeLabs Experiments. Ann. Assoc. Am. Geogr. 2015, 105, 425-436. [CrossRef]

13. Mukhtar-Landgren, D.; Kronsell, A.; Voytenko Palgan, Y.; von Wirth, T. Municipalities as Enablers in Urban Experimentation. J. Environ. Policy Plan. 2019, 21, 718-733. [CrossRef]

14. von Wirth, T.; Fuenfschilling, L.; Frantzeskaki, N.; Coenen, L. Impacts of Urban Living Labs on Sustainability Transitions: Mechanisms and Strategies for Systemic Change through Experimentation. Eur. Plan. Stud. 2019, 27, 229-257. [CrossRef]

15. Sengers, F.; Berkhout, F.; Wieczorek, A.J.; Raven, R. Experiments in the city: Unpacking notions of experimentation for sustainability. In The Experimental City; Routledge: London, UK, 2016; pp. 15-31.

16. Schot, J.; Geels, F. Strategic Niche Management and Sustainable Innovation Journeys: Theory, Findings, Research Agenda, and Policy. Technol. Anal. Strateg. Manag. 2008, 20, 537-554. [CrossRef]

17. Loorbach, D. Transition Management for Sustainable Development: A Prescriptive, Complexity-Based Governance Framework. Governance 2010, 23, 161-183. [CrossRef]

18. Abraham, M.; Bharadwaj, S.; Chambers, R.; Hueso, A.; Joseph, M.J.; Mukerjee, R.; Myers, J.; Narayanan, P.; Raman, V.R.; Sarkar, S.; et al. Using Immersive Research to Understand Rural Sanitation: Lessons from the Swachh Bharat Mission in India. In Proceedings of the 41st WEDC International Conference. Transformation Towards Sustainable and Resilient Wash Services, Nakuru, Kenya, 9-13 July 2018.

19. Birch, I.; Catani, R. Immersions: Reflections on Practice. Particip. Learn. Action 2007, 57, 133-139.

20. Osner, K. With the Strength of the Powerless: Using Immersions for Processes of Structural Change. Particip. Learn. Action 2007, $28,128-132$.

21. Williams, H. The Secret Security Guard. Being a G4S employee during the London Olympic Games 2012. In Engaged Urbanism. Cities E Methodologies; I.B. Tauris: London, UK, 2016; pp. 87-96.

22. Giddens, A. The Politics of Climate Change; Polity Press: Cambridge, UK, 2009; ISBN 9780745646923.

23. Grin, J.; Rotmans, J.; Schot, J. Transitions to Sustainable Development: New Directions in the Study of Long Term Transformative Change; Routledge: New York, NY, USA, 2010; ISBN 9780415876759.

24. Swilling, M.; Annecke, E. Just Transitions. Explorations of Sustainability in an Unfair World; UCT Press: Cape Town, South Africa, 2012; ISBN 5856420187.

25. Kemp, R.; Loorbach, D.; Rotmans, J. Transition Management as a Model for Managing Processes of Co-Evolution towards Sustainable Development. Int. J. Sustain. Dev. World Ecol. 2007, 14, 78-91. [CrossRef]

26. Kemp, R.; Schot, J.; Hoogma, R. Regime Shifts to Sustainability through Processes of Niche Formation: The Approach of Strategic Niche Management. Technol. Anal. Strateg. Manag. 1998, 10, 175-198. [CrossRef]

27. Geels, F. Technological Transitions as Evolutionary Reconfiguration Processes: A Multi-Level Perspective and a Case-Study. Res. Policy 2002, 31, 1257-1274. [CrossRef]

28. Geels, F. Technological Transitions and System Innovations; Edward Elgar Publishing: Cheltenham, UK, 2005.

29. Ellen MacArthur Foundation. Towards a Circular Economy: Economic and Business Rationale for an Accelerated Transition; Ellen MacArthur Foundation: Cowes, UK, 2013; Volume 1, Available online: https://www.ellenmacarthurfoundation.org/assets/downloads/ publications / Ellen-MacArthur-Foundation-Towards-the-Circular-Economy-vol.1.pdf (accessed on 22 February 2021).

30. Levy, C. The Process of Institutionalising Gender in Policy and Planning: The Web of Institutionalisation; Working Paper No. 74; Development Planning Unit, University College London: London, UK, 1996.

31. Karvonen, A.; van Heur, B. Urban Laboratories: Experiments in Reworking Cities. Int. J. Urban Reg. Res. 2014, 38, 379-392. [CrossRef]

32. Rip, A. The Context of Innovation Journeys. Creat. Innov. Manag. 2012, 21, 158-170. [CrossRef]

33. Hoogma, R.; Kemp, R.; Schot, J.; Truffer, B. Experimenting for Sustainable Transport: The Approach of Strategic Niche Management; Spon Press: London, UK, 2005; ISBN 9781134488223.

34. Vermoesen, K. OOp Zoek Naar Brownfields? Haal Meer Uit Je Brownfield Event. 2019. Available online: https://www.ovam.be/ haal-meer-uit-uw-brownfield-0 (accessed on 22 February 2021).

35. McFarlane, C. Learning the City; Wiley-Blackwell: London, UK, 2011.

36. Verheyen, J.; Tempst, W.; Luyten, E.; Devoldere, S. Pilootprojecten Terug in Omloop; Newton, C., Ed.; Vlaams Bouwmeester: Brussels, Belgium, 2015; ISBN 978-90-4030-370-8.

37. Malik, A. After Modernity: Contemporary Non-Western Cities and Architecture. Futures 2001, 33, 873-882. [CrossRef]

38. Vlaanderen. Vision 2050. A Long Term Strategy for Flanders; Departement Kanselarij en Bestuur: Brussels, Belgium, 2016.

39. Pieterse, E. Building with Ruins and Dreams: Some Thoughts on Realising Integrated Urban Development in South Africa through Crisis. Urban Stud. 2006, 43, 285-304. [CrossRef]

40. Spivak, G. The Rest of the World. In Hope: New philosophies for change; Zournazi, M., Ed.; Pluto Press Australia: Annandale, NSW, Australia, 2002; pp. 172-190.

41. Pieterse, E. City Futures. Confronting the Crisis of Urban Development; UCT Press: Cape Town, South Africa, 2008. 
42. Pieterse, E. At the limits of possibility: Working notes on a relational model of urban politics. In Urban Africa. Changing Contours of Survival in the City; Simone, A., Abouhani, A., Eds.; Codesria Books: Dakar, Senegal, 2005.

43. Mouffe, C. For a Left Populism; Verso: London, UK; New York, NY, USA, 2018.

44. Foucault, M.; Blanchot, M. Michel Foucault: Maurice Blanchot: The Thought from Outside/Maurice Blanchot: Michel Foucault as I Imagine Him; Zone Books: New York, NY, USA, 1990; ISBN 0942299027.

45. Simons, J. Foucault and the Political; Routledge: London, UK, 1995.

46. Foucault, M. What is Enlightenment? In The Foucault Reader; Rabinow, P., Ed.; Pantheon Books: New York, NY, USA, 1984; pp. 32-50. 